\title{
THE MOUTH THAT LAUNCHED A THOUSAND RIFTS: SANDRA BERNHARD'S POLITICS OF IRONY
}

\section{Catherine Halley}

Remember, Razumov, that women, children, and revolutionists hate irony, which is the negation of all saving instincts, of all faith, of all devotion, of all action.

Joseph Conrad, Under Western Eyes ${ }^{1}$

My problem is that I've never been a phony.

Sandra Bernhard ${ }^{2}$

The political climate calls for somebody to be a little bit more forthright, especially somebody like me who's all about, supposedly being real.

Sandra Bernhard ${ }^{3}$

I'm never quite sure how to respond to Sandra Bernhard because I never know if she is telling the truth. I remember when I first saw her at a masked ball at Vassar College in 1989. Her cameo appearance in an orange mini-dress and spiked heels created quite a sensation for those of us who had skipped her standup show in order to attend this exclusive, annual event sponsored by the Art History department at Vassar. She danced with my friend Joey for about five minutes and then, like most famous people who deign to make such impromptu appearances, she decided to leave. This was during the heyday of the MadonnaSandra controversy, so I felt it only appropriate to make my mark, to ask if it were indeed true that they were lovers. (Like Sandra, I'm an exhibitionist and I was hoping to have a good story to tell in the future.) I reached up, tapped Sandra on the shoulder and asked my "outrageous" question without realizing that every interviewer she ever met asked the same thing. "Are you and Madonna lovers?" I asked, for some reason expecting an honest answer. "Not Yet," she said slowly, affecting a coy tone and turning to get into her limousine. I laughed, but I had no idea whether Sandra was telling me the truth. 
And thus I was introduced to Sandra's notorious propensity for ambiguity. I asked her to answer me, yes or no, but she instinctively chose a position in between. In effect, she answered my question by suggesting others. Did she mean to become Madonna's lover in the future? Was Sandra's love for Madonna unrequited? Or vice-versa? Her open-ended answer made me anxious and confused. She would, I suppose, like this response. A comment she makes to Bill Zehme in Rolling Stone suggests that this is exactly how she wants people to respond to her. "I want people just to not know what's going on. To be just a little bit confused and irritated and say, "Who does she think she is?"'4 I asked this of her that night at Vassar, and in some ways the question stands.

Four years later, I am drawn to Sandra Bernhard's "mockumentary" Without You I'm Nothing - a film Lynn Hirschberg finds bold enough to merit the epitaph, "a docudrama of an ego on the loose"-precisely because of its ambiguous tone and its campiness. ${ }^{5}$ This essay is in part an attempt to understand how Bernhard uses strategies of camp humor, such as irony, hyperbole, and parody, to political ends in the film. Specifically I consider how her use of suggestive diction and tone, juxtapositions, and disjunctions serves to denaturalize and complicate stereotypes based on gender, sexuality, and race. I also consider the limitations of these methods that the film's director John Boskovich, dubs “informed, deconstructive comedy cabaret” (Quoted in Zehme 79).

In her essay "Notes on Camp," Susan Sontag says something that will help explain both my current understanding of Bernhard and my understanding of her ironic sense of humor as a phenomenon of camp.
Camp sees everything in quotation marks. It's not a lamp, but a "lamp": not a woman, but a "woman." To perceive Camp in objects and persons is to understand Being-as-Playing-a- Role. It is the farthest extension, in sensibility, of the metaphor of life as theater. ${ }^{6}$

I have developed a campy relationship to Sandra Bernhard-I see her as "Sandra" not Sandra, "fierce" not fierce-because I recognize her "Being-asPlaying-a-Role."7 But at the same time, I contend that she presents herself as someone who "sees everything in quotation marks," who celebrates the artifice of the "supposedly real," and who is "alive to double sense," all characteristic of camp according to Sontag (110). Bernhard is constantly theatrical. In other words, she "knows herself to be Camp," (she "is camping" or "camps it up") and so would be exempt from so-called "pure or naive Camp" (112).

Sontag suggests that "intending to be campy is always harmful" because it threatens to be too heavy-handed. Although she is aware of her own campiness, Sandra Bernhard avoids this — she "reeks of self-love," but maintains the front of innocence vital to campy effect (111). Consider how she insists on her naiveté: "If you think [my humor] is sarcastic, then you're missing the vulnerability. I think my work is more about honesty than it is about anger [or biting sarcasm]." 8 Here, as in other places, Bernhard assures her interviewer that 
she is not sarcastic - which is by definition more vindictive than irony-she claims to be too vulnerable and too subtle to be sarcastic. While I might have argued otherwise four years ago, now I agree, Sandra isn't really sarcastic. She doesn't simply say the opposite of what she means in order to "wound another." 9 Instead, she exposes the irony embedded in most truths. Ultimately, her humor is based on the polyvalence of her text and the ambiguity of her tone-on that "double sense" that Sontag talks about-and on her mastery of irony.

Joseph Conrad suggests that ironists cannot be faithful, devoted, or active. Susan Sontag, who posits Camp as the triumph of irony over tragedy and identifies it as celebratory, also insists that it is "disengaged, depoliticized-or at least apolitical" (107). In contrast, Michael Musto suggests that only what he calls "old camp" - fueled by fury and insecurity — admits defeat, and might, therefore, be called apolitical. "New camp," on the other hand, "derives from self-assuredness," and represents "a new style bonding that bolsters confidence and wit [of gays and lesbians]."10 Musto identifies Bernhard as "new camp." Like Bette Midler, he maintains, she is "an aggressor, not an object," who "dissects topical personalities, while looking fabulous" (Musto 37). New camp, Musto implies, is dedicated especially to queer causes, and is hence, more political. ${ }^{11}$

Andrew Ross also finds camp celebratory and politically powerful. While he is interested in exposing the counter-cultural elitism of camp, he also wants to identify its successful "uses" and its political import. Like Musto, he is confident in its subversive power, but his more analytical approach allows him to be more specific about its politics. Rather than in its "counter-cultural" tastes, he points to drag as the site of camp's political power-to its deconstruction of sexuality and gender identity-something which Sontag generally ignores and which Musto does not complicate. ${ }^{12}$

Sandra Bernhard, however, does not do drag in the conventional sense of the word-she rarely dresses as a man. But her femininity is exaggerated such that it becomes a form of drag. Indeed, she is a drag queen instead of a drag king, who turns femininity into a costume and exposes her masquerade by constantly talking about "glamour." 13 On the other hand, she parrots the fashion industry so well that she seems rather serious at times. Something Christopher Isherwood says about camp might help put this in perspective. Sandra "expresses what's basically serious [to her] in terms of fun and artifice and elegance."14

But is Sandra really serious about glamour? Yes and no. It is true that Sandra appears frequently in fashion magazines and recently has been doing "runway" shows for Chanel and Isaac Mizrahi, but she does this with a determination to undermine traditional notions of beauty and "proper" womanhood. She insists that her body and her face can and do work (in) those clothes so often reserved for women with small noses and no hips. ${ }^{15}$ While she does subscribe to some notion of beauty and glamour, she does so with a vehemence hard to mistake for the usual brand of voiceless super-model.

Indeed, consider her response to David Letterman when he asked, "What's the story with your outfit?" Sandra replied: 
"The story is Mizrahi, darling, as always," Bernhard snaps. "We are giving Mizrahi tonight. We are giving Oribe on hair, we are giving Helena on makeup....We are giving high glamour and the audience loves it. They need it, they desire it, they reach out for it? Sexual tension!'16

What she means is that the audience wants her because of how she is dressed. Jesse Green obviously picks up on Bernhard's "camping," since he transcribes the designer names in italics in an attempt to capture Sandra's fabulous tonal inflections. Bernhard's campy attitude makes it clear that her brand-named beauty is a gift to the audience that they expect and need. Her high glamour is itself a performance of "sexual tension." Thus, Sandra becomes a sexual object - a sexed and gendered person, a Woman-for the audience. She is willing to "fashion" herself into a gendered and sexed being and demonstrates how fashion functions to create sexed and gendered bodies. She parodies womanhood and exposes it as artificial, all with the "mouth that roars" as one of her interviewers dubs her. In her film, Sandra's talk reminds us that "beauty" and "glamour" also function to "race" us, which may just be an erasure for some people. Even in her interviews, although we see how her "boxer's" [read Jewish] nose and full lips [which have been described as "nigger lips"] explain why she has been tagged "jolie-laide (pretty-ugly in French)."17 Sandra transforms the pain that tag has caused her and turns it into powerful venom in her work. She insists on loving herself as she is. As Jesse Green says, "Liberation for Bernhard begins as a private affair: in the crucible of one's own body" (Green 42).

Green is right to say that "liberation begins as a private affair" for Sandra, because she soon turns her own abjection into public defiance. She refuses to be silent about the ironies and ugly truths of the fashion industry and this seems to be the place where her shtick about beauty and glamour become political. Not only does she indirectly create a space for women to be who they want to be, but she exposes the ways in which "one is not born, but becomes a woman," to borrow de Beauvoir's phrase, when we are gendered and, Sandra seems to imply, raced. ${ }^{18}$ In her interviews she recognizes the raced body as a kind of trap, but she also insists that the body is a sight of resistance and potential freedom. "I never had a nose job and consequently I became the girl I wanted to be," she says, reminding us that conventional notions of beauty are waspy and white (Green 42).

In her movie, Without You I'm Nothing, she also insists the body is a site of liberation, and combines her critique of beauty and glamour with a disturbing critique of racial difference. Reviewing her live version of the show at the Orpehum in New York, Village Voice critic, Gary Indiana says that it "deals with the social construction of identity, the self mediated through and collaged from the realm of the symbolic. Bernhard's stage-persona corresponds to the self-aspastiche." 19 The film version of Without You I'm Nothing also deals with "the social construction of identity" and with "the self-as-pastiche," but only in the film version does she deal with the construction of a racialized as well as a 
gendered and sexualized self.

The film, written by Bernhard and John Boskovich, is a veritable fashion show, devoted to the manifestation of Sandra in various modes of glamour. From the Chanel-clad Jewish woman of New York's Upper East Side to the black nightclub singer in orange pantsuit, Sandra performs each with the nostalgia and attention to artifice that are characteristic of camp. Her costume changes ask the question, "If you look and act like a particular kind of person, are you that kind of person?" As she changes clothes, Sandra changes personalities-but she revises the old maxim that "it's the clothes [and the body, she would add] that make the girl." Her clothes are worn parodically—such as when she wears a "Chanelesque" dress and does a monologue about Andy Warhol's estate auction where she goes with a group of rich, New York Jewish celebrities such as Ralph Lauren, a.k.a. Lifshitz, who "pass" as gentile.

In this scene Bernhard plays what might be construed as a version of herself, but not all the monologues are so realistic. In fact, Sandra seems to represent the inauthentic. Donning an orange pantsuit and long red nails, she becomes a black nightclub singer who gets along with her Jewish piano player ("we people get along so well," she says sardonically right around the time of the Crown Heights incident in NYC). In truth, and this is the crux of the humor of this film and perhaps the "problem" that she refers to in the epigraph to this essay, the piano player is African-American and Sandra Bernhard is Jewish. The joke depends ultimately on something we recognize as essentially true. As she changes race, class, gender, and sexuality in her monologues, she exposes her own artificial occupation of these positions - essentially, she is not a black nightclub singerand we laugh because we know this. Thus, our recognition of the disjunctions between who Sandra claims to be and who she actually is exposes our belief in essence or authenticity.

At the same time, however, her easy mutation between roles reveals how our understanding of stable racial, class, gender, and sexual identities also relies on non-essential, even arbitrary characteristics like clothes, gestures and affectations which are easily imitated and appropriated by someone who does not possess the "essential" characteristics of that identity. Thus, Sandra Bernhard can "pass" as black, and she almost does during an early scene in the film, by acting and calling herself black. She sings Nina Simone's song, "Four Women," and belts, "My skin is black" under lighting which makes her skin tone darker than it actually is. At this moment, we are forced to reassess what that line, "My skin is black," means-how do we determine blackness in a world where very few people who are dubbed "black" actually have black skin-when black can mean brown and yellow and a whole range of skin tones? I will return to this scene in a moment, but first let me turn to the earlier scenes that establish that Sandra is "actually," in so far as someone of Jewish heritage can be called, white.

For the most part, the film depicts a performance of a performance-Sandra is on stage, performing to an audience which is mostly African-American. However, the first scene of the movie takes place backstage. The first lines of the movie delivered by the "authentic (white) Sandra" are particularly biting. "You 
know, I have one of those really hard-to-believe faces," she says. She draws her nose and lips together: "It's sensual, sexual; at times, it's just downright hard-tobelieve. I wish you could kiss me right now. Just this side of my nose. (Blows kiss) Just a silly little peck, so to speak, as it were. I am so glad you can see how truly beautiful I am. Right now," she says tossing her head. It is a gesture of intimacy and confidence, but even the "authentic Sandra" is exposed as a fake. ${ }^{20}$ At first she seems self-aggrandizing-she calls her own face "sexual and sensual" and "truly beautiful"-but this is complicated by the apparent disjunction between her own assessment of her face and what it actually looks like. At first glance it is not sexual or sensual, nor particularly beautiful, at least not according to the stereotypes endorsed by popular culture. Her attitude dares us to disagree, however, and the conviction with which she delivers these lines makes us question our assessment of her beauty and hopefully, beauty in general, in the same way we must question our assessment of "blackness" in the scene I discussed above.

In fact, the scene with Sandra in front of her dressing room mirror may be read as a response to and an attempt to disarm those critics who have called her "jolie-laide," who have commented on the size of her lips and the shape of her nose. The film attempts to strike a balance between subtlety and anger that Sandra does not always successfully do. In Vanity Fair, for instance, she says, "I'm described all the time as "jolie-laide' the beautiful-ugly thing," she says with no small amount of outrage."And it's like, 'Fuck you, man.' I'm not some blonde bimbo, but I'm fucking hot. A lot of people want to fuck me" (Hirschberg 141). As this outburst demonstrates, Bernhard is painfully aware that beautiful means Caucasian and blonde to a lot of people and particularly to those with the power to regulate and control the standard images of beauty that are circulated through culture by way of the fashion industry. Her tone in the movie is much more confident and less defensive, but beneath both comments I detect her vulnerability and her seriousness.

Nevertheless, the first lines of the movie are punctuated by gestures which indicate that the film is comic, even campy. When we first see her, her gaze is directed downward, as she puts cosmetics in a drawer, pats it shut and anally cleans her vanity top with glass cleaner-she performs even without an audience. She doesn't notice us as she leans into the mirror and clips small pieces of her hair with no visible result. The camera comes around to her profile and then she looks directly at it and addresses her first words to it and perhaps, to us, the "you" that appears in italics in the film's title. Bernhard disrupts our notions of a glamour girl in front of her mirror because of the aggressive stance she takes towards the camera. She acts like Marilyn Monroe blowing kisses at the camera, but she does it aslant, exaggerating her own beauty so that her words become parodic and self-parodic. She "reeks of self-love," something Susan Sontag recognizes as camping.

Her personal manager, Ingrid Horn, who is "interviewed" right after this scene confirms that Sandra is egotistical. She tells us that Sandra has gotten "too grand, way out of hand" after her success on Broadway with her "smash-hit-one- 
woman-show," Without You I'm Nothing. ${ }^{21}$ Horn serves to contain our "disgust" at Sandra's vanity since we are assured that she is being punished for it. She tells us, 'I said, 'Lady, you've got to get a grip on yourself.' We had to pull the reigns in on her, so we came back to L.A., where she began. (Pause, points at the camera) To her roots, [presumably to learn a little humility], to upscale supper clubs like the Parisian Room." 22 And thus, Horn explains why Sandra performs "cabaret comedy" during the majority of the film for what turns out to be a mostly AfricanAmerican audience.

Horn reappears later in the film, right before Sandra does a version of "Ain't No Mountain High Enough," to assure us that "Sandra has no influences. In fact, they've all stolen from her....Nina Simone, Tina Turner...I've even seen traces of Sandra in Diana Ross." This absurd reversal of white appropriation of black culture drives home the relationship between Sandra and African-American women which has been alluded to throughout the whole film through various techniques including the "race-drag" that I discussed earlier and the juxtaposition of images of Sandra and Vanessa Burch, the female, African-American piano player in "Sandra's" band.

We learn to read these juxtapositions early in the film which begins with a white man dressed in eighteenth-century clothes (he even wears a powdered wig), playing the harpsichord. At first he plays alone, but eventually is accompanied on the piano by an African-American woman dressed in contemporary clothes who seems to represent the "authentic." As the camera pans to her profile, Sandra Bernhard's name appears on the screen as part of the film's beginning credits. The logical assumption, for those who don't know her, is that Sandra is the woman we see playing the piano. Ironically, this woman, played by Vanessa Burch, turns out to be the piano player during Sandra's performances throughout the movie. Images of the two women's profiles and hands are occasionally juxtaposed.

Right after Ingrid Horn is interviewed the first time and we discover that Sandra will be performing at "upscale supper clubs" in L.A., the film cuts to a group of African-American musicians, including Vanessa Burch, smoking marijuana as they prepare to play. The whole scene uses exaggeration to disrupt stereotypes of black jazz musicians in several ways. First of all, the film is shot in slow motion and the camera fragments the bodies of the musicians; it isolates profiles, mouths, and hands. The camera angles evoke the feeling of "getting high" in this way, but they also fetishize the parts of the "black body" such as lips and noses which have been used historically to assign race to a particular body. The sound of horns paired with profile shots of a man blowing marijuana smoke out of his mouth, for instance, exposes the stereotype that black musicians have to be high to make music.

As the musicians get ready to play, Burch snaps and counts out a rhythmher hand is centered in the profile shot-which turns out to be shockingly slow compared to the rushed music the band plays. A few minutes later, the screen shows nothing but what looks like a white person's hand snapping during the introduction to Nina Simone's "Four Women." The hand turns out to be 
Sandra's. Although we now know the hand is white, the signification of "blackness" is questioned since the movie and media, in general, have fetishized and derided Sandra's face and body in a way similar to the "the black body." In fact, after her first stand-up show Paul Mooney, an African-American comic, approached her. He said, "I knew what hell Hollywood was gonna put her through. Her look wasn't what they wanted. She's thin, she's very aggressive, and she's got the big nigger lips. That's not what they fall in love with. They were all threatened by her face, her sexuality" (Zehme 80). Mooney predicted that Sandra's body would cause her trouble and, indeed, it has.

Ten years later, the film responds to this by pointing to the irony of racial tags through the use of close-ups of Sandra's face, mouth, hands and profile juxtaposed to the same close-ups of African-Americans. This irony is further sketched out when Sandra begins to sing her opening number, Nina Simone's 1966 song, "Four Women," which explores four stereotypes of black women. Simone writes about the song in her autobiography.

The women in the song are black, but their skin tones range from light to dark and their ideas of beauty and their own importance are deeply influenced by that. All the song did was to tell what entered the minds of most black women in America when they thought about themselves: their complexions, their hair-straight, kinky, natural, which?-and what other women thought of them. Black women didn't know what the hell they wanted because they were defined by things they didn't control, and until they had the confidence to define themselves they'd be stuck in the same mess forever-that was the point the song made. ${ }^{23}$

Sandra has a similar agenda to interrogate the inscription of culture (e.g., race and gender) on the body and to redefine beauty. The song begins, "My skin is black." Not only does the obvious disjunction between the words that Sandra sings and the (white) color of her skin call "blackness" into question, it calls Sandra into question. She is posited as an inauthentic performer-she is someone who naively and guiltlessly appropriates African-American culture-or a performer of the inauthentic-she consciously calls into question her own performance of this song as fraudulent and appropriative. By the time Ingrid Horn shows up to assure us that "they've all stolen from Sandra," including Nina Simone, the latter reading makes the most sense.

My own response to this song has ranged from discomfort-why is she singing this song - to enlightenment-it makes me aware of her own construction as a white person-to delight-she has such chutzpah, to perform a Nina Simone song to an audience which in the film is all black and clearly uninterested, unimpressed and annoyed-one woman even rolls her eyes. Most of the audience talks throughout the three verses she does perform and they refuse to clap when she finishes, changing the last words of the song to "My name is 
Peaches." 24 She looks up into the spot lights with hands up in the air and a huge, stage smile on her face. The silence is painful, but it is also "what she deserves" as a white woman appropriating Simone's song and then singing it horribly.

As Sandra reveals in Interview, the audience response is planned.

"The audience is completely manipulated. They don't respond to me at all. They're just staring at me like, 'Who is this white bitch?'

"We're using the black audience as a metaphor for being on the outside," she says. "I'm really proud of the stance we're taking in the movie, without being really obvious or didactic and heavy. It's really up to you. If you're a racist, you're going to see things in the movie that might anger you because they remind you of your racism. I'm sure there are going to be a lot of mixed reviews." (Chua 38, my emphasis)

With each performance, she evokes the same response. Sandra is an outsider in this black club the way that African-Americans are outsiders in white America and this relationship of common exclusion between herself and African-Americans frames and is explored throughout the movie, although the exact nature of that relationship is never clearly explained.

Why does she choose to "use" African-Americans "as a metaphor for being on the outside?" In part, she feels that black culture influenced her as she grew up during the 1960's in Flint, Michigan. She says, "There were a lot of black people who were influential in the city I came from. They were an important part of formulating my ideas about the world. That's why it's always so shocking to me that we're back to this racism." A new kind of racism prevails, "a strange hybrid. It's like designer racism" (Taylor 38). In claiming the influence of black culture, Bernhard wants to assert that she is not racist and to confess the affinity she feels with African-Americans, which is meant to justify her "use" of them in her film. In the passage from the Village Voice that I cited above, her language seems characteristically contradictory - "we're using the black audience," they are "completely manipulated," yet she claims to be "taking a stance in the movie, without being really obvious or didactic and heavy." It is unclear what kind of a stance she takes. About what? Against racism? Against appropriation of black culture which she ironically claims to use to her own ends? By failing to say what she stands for "obviously" or "didactically," Bernhard admittedly opens up the film and herself to racist interpretation.

In bell hooks' terms, she "walks a critical tightrope....Bernhard's Jewish heritage as well as her sexually ambiguous erotic practices...place her outside the mainstream" (hooks 37). But Bernhard has much more power than most AfricanAmericans. She controls her own career, while many of the black female singers she imitates had their songs written by Burt Bacharach and were steered toward tragedy by the white music industry. So what makes Sandra's experience of marginalization similar enough to that of African-Americans that she feels 
comfortable comparing herself to them? It is my contention that Sandra's experience of marginalization takes place, like African-American's, at the very cite of her body. It is the pain that this has caused her-particularly evident in the Vanity Fair article when she claims that "people still want to fuck her," even if she's "not some blond bimbo"- that allies her to African-Americans whose own black bodies have also become metonymic of their oppression. It is this pain in fact which seems to drive her preoccupation with the body and its dressings in all of her work.

As I hope to show through my analysis of the interviews she has done in the past few years, Bernhard is not derided because of her "ethnicity" and "sexuality"- -she says "to discuss my sexuality at this point would be redundant." 25 Instead, it is her body, which has become metonymic for these things, that is derided. Indeed, the discourses of racism and homophobia still prevail in her interviews-she is still marginalized because of her "Jewish heritage" and "ambiguous sexual practices"—-but they are masked by a discourse about beauty and glamour. Bernhard's Jewishness and "bisexuality," are discussed in euphemistic terms. She is an outsider because of her "inflated lips" and her "boxer's nose," because she is "loud" and will only admit to "acting lesbian" (Burana 70). The serious is displaced onto the frivolous where Bernhard picks it up and turns it into camp-remember Isherwood's comment about how camp "expresses what is basically serious in terms of fun and artifice and elegance"?

But does camp humor work to denaturalize and deconstruct race as well as it does to deconstruct gender and to denaturalize heterosexuality? How does her audience respond to the connection alluded to between Bernhard and AfricanAmericans? Can a viewer of her film who has not read her interviews understand the connection from the film alone? Bernhard's tendency to allude to connections instead of directly explaining them is typical of parodic discourse and camp humor in general. She calls this technique "interrogative."
It's easy to let people know exactly where you are. It's more interesting to let them know that you're thinking about things on a couple different levels and that it's up to them to figure it out. When you present material in a more interrogative way, they're forced to go away and think about it. (Taylor 141)

But what are we to think? Indeed, it seems apparent that Sandra is "thinking of things on a couple different levels." To me, the film seems too complicated for people to leave it with all of their racist assumptions in place, but I am not sure that this is an indication of the film's successful deconstruction of racial difference.

In fact, the end of the film seems, at first, to reinscribe racial difference and animosity. The last scene shows Sandra Bernhard, dressed in an American flag, "knocking off the fame shit" and coming clean with her audience. She admits that she is "a phony and a fraud, and that everything she said [to them] was a complete lie." She wishes she could give the audience back "every penny they spent" to 
see her, but she can't because as she admits to them, "without you, I'm nothing." 26 Presumably she has learned the lesson of humility that she has been brought to L.A. to learn. She speaks nostalgically about wanting to be the kind of person that saw the side of America that few people see. As a tribute to the person she wants to be and to the audience whom she claims she "will always love," she does a striptease to Prince's "Little Red Corvette." At the end of the song, only one young black woman is the left in the theater. Roxanne, as she is named in the credits, has silently haunted the film. Throughout the film, she has drifted across the screen doing both things that black women, in white society's estimation of them, do not usually do-like read Kaballah and Criticism in front of a kosher meat store-and might very well do in that estimation-like walk apprehensively, in a towel, through a public shower full of naked, white women who are soaping each other up. ${ }^{27}$

While I have discussed the ways in which Bernhard is compared to the piano player, Vanessa Burch, many people, including bell hooks, discuss the enigmatic relationship between Bernhard and Roxanne. hooks asks, "Is she [Roxanne] the fantasy Other Bernhard desires to become? Is she the fantasy Other Bernhard desires?" (hooks 38). Just as Burch and Bernhard were compared early in the movie, a similar image of Roxanne and Bernhard looking in the mirror and clipping tiny pieces of their hair draws them together. In these instances, Bernhard, vainly primping in front of her dressing room mirror, seems to represent the inauthentic_-even alone in her dressing room, she performs some version of herself, while Roxanne, who listens to the rap group NWA (short for Niggers With Attitude) in her own bathroom, represents the authentic-she never even notices the camera as she dances to a song produced by "her own" people. ${ }^{28}$ But both women are inscribed by the culture of the other. Bernhard's deliberate appropriation of black culture is seen throughout the whole movie, and Roxanne-whose straightened hair marks her body with whiteness-reads Jewish rabbinical criticism.

The film ends when Bernhard realizes that most of her audience has disappeared even as she stands practically naked before them. Sandra is deflated. She looks forlornly out into the empty theater until she spots Roxanne who returns Sandra's stare with what hooks calls a "contemptuous gaze." Indeed, Roxanne refuses to be the audience which will make Sandra "something," rather than "nothing." She calmly writes "fuck Sandra Bernhard," in red lipstick on the table in front of her, then she gets up to leave. Bell hooks suggests that "her message seems to be: 'you [Sandra] may need black culture since without us you are nothing, but black women have no need of you" " (hooks 38). I agree that this last gesture is a rejection of Sandra. It is the refusal that she has deserved-à la Horn-since the beginning of the film, but I don't think that it means that "black women have no need of" white women.

The end of the film does seem to project racial animosity, but I think that its final image - of Roxanne walking slowly out the door of the theater and disappearing into whiteness-still tries to deconstruct racial difference and suggests that even the "authentic" (Roxanne) is inscribed with or can be 
subsumed by its Other or that which others it. Roxanne can turn her back on Sandra so that Sandra-absorbed into blackness-is nothing, but Roxanneabsorbed into whiteness-becomes nothing too, or at least something besides an "authentic" black woman. Thus, the ending seems to endorse a kind of racial relativism which denaturalizes racial categories as absolutes. Both women's racial identity is contingent on the other's in a way that is never, perhaps because of Sandra's preference for the ambiguity of irony, made clear in the film. But what does it mean for a white woman to point to the instability of categories of racial identity? Even if she does feel her body has been demonized like the "black body" in America and even if she speaks experientially from a position of the Other, this critique might be a privileged argument to make. ${ }^{29}$

Throughout the film, Bernhard uses camp in order to exorcise her body of its demonization. The black people in the film, however, do not get the same chance to liberate their own bodies. bell hooks says, "Black women have no public, paying audience for our funny imitations of white girls" (hooks 38). Although their bodies are exorcised, it is Sandra's campy relationship to them that performs this ritual. Sandra controls the ways in which black bodies are exaggerated (through fragmentation), used to perform authentic blackness (audience responses), and denaturalized (by Sandra's own race drag). Whereas Sandra intends to be campy, the black people in this film are "naive Camp," in Sontag's formulation of the phrase, because they do not intend to be campy. This is what leads hooks to say that Bernhard "mocks black women," in her movie, because they are the object of humor without meaning to be (hooks 38). ${ }^{30}$

Bernhard has an agenda - to "fight sexism, racism, and homophobia" with "the funk"- which she screams during the only directly political part of the movie. She claims that "her anthem and her goal in life" is something Patti Smith once said: "I may not have fucked much with the past, but I've fucked plenty with the future." "I'd like to believe in that quote," she says. So we might understand Sandra's agenda as a desire to "fuck with the future," but the future she seems to be "fucking with" is not just her own. If she does mean to deconstruct racial difference in order to "fight sexism, racism and homophobia," as I have tried to show in this essay, then it seems that she assumes that black people share her agenda and her camp strategies as well. But there is a disparity between Sandra's intended campy effect and the black people's unintentional campy effect. Consequently we have seen how camp's tendency to be suggestive rather than direct opens up Sandra's film to racist interpretations.

This raises the question again about whether Bernhard's use of camp is as effective in deconstructing race as it is in deconstructing gender or sexuality. Is her use of camp simply an irresponsible appropriation of the Other? bell hooks is not optimistic about the possibilities of reading this film: "Blackness is the backdrop of Otherness she [Bernhard] uses to insist on and clarify her status as Other, as cool, hip, and transgressive, [and I would add campy]....Like her entertainment cohort Madonna, Bernhard leaves her encounters with the Other richer than she was at the onset. We have no idea how the Other leaves her" (hooks, 39). For hooks, this kind of appropriation and manipulation of the 
Other-despite Bernhard's admitted identification with black people—is like a meal during which Bernhard "eats the other." She explains, "[t]he over-riding fear is that cultural, ethnic, and racial differences will be continually commodified and offered up as new dishes to enhance the white palate- that the Other will be eaten, consumed, and forgotten" (hooks 39). But I have tried to demonstrate how Bernhard wants to offer not a meal of different courses arranged carefully on a plate, but a casserole perhaps, in which all of the food, all of the Others, are mixed together with the self, so that consuming the Other invariably involves consuming the self. ${ }^{31}$

But of course (no pun intended), this assumes a particular audience is watching the film-one which can conceive of consuming itself. This is a position of luxury and privilege, to think of the self as something which may be mixed with Others and eaten like food. It assumes an ironic distance from, or a campy relationship to, the self-as Sontag says, "understanding 'Being-asPlaying-a-Role' and an investment in the post-structural project of deconstructing the subject" (109). This is precisely the "cultural elitism" of camp that worries Andrew Ross when he says that "Camp would thus be reserved for those with a high degree of cultural capital" (10).

I have come around to the same vigilance and ambivalence I felt when I first tapped Sandra Bernhard on the shoulder at Vassar, before I really knew what camp and irony were. With this vigilance which I have not meant to abandon throughout the paper and choose to foreground at the end, I must return to hooks' fear and to her question. Does Sandra Bernhard offer up racial difference to the "white palate" where it will be "consumed and forgotten?"

It would be wise in the interest of remaining vigilant to the extratextual influences which determine camp's and irony's political import, to consider this question in the context of a real audience. Although I have seen the film four times in public, I do not feel confident that this would give me the evidence necessary to ascertain whether Otherness is "consumed and forgotten" by the film's real audiences. Instead, I have chosen, by introducing an element of selfreflection into this paper, to contextualize my own reading of the film and to admit and explore the ambivalence I feel about the film's attempt to deconstruct race through strategies of camp. I hope that in this final moment, when I feel somewhat smug about reaching such a clean ending, that I have found a way to desanitize my own reading of Bernhard.

If I ask confusedly, as I am want to do, "Who does she think she is?" then I play her perfect audience again, and am no further along than I was four years ago when I felt ashamed by her refusal to answer my question about Madonna. But what if I refuse the position she tries to put me in? What if, instead of thinking about just what Sandra's trying to do, I do what hooks thinks is most important, and look critically at her images of blackness (and attempts to liberate it) as I mean to have done in this essay? Then am I the right audience for the film?

C. Carr writes about Sandra's relationship to consumer culture in Artforum magazine. She says, "Sandra refuses to be the right sort of spectator" which I take to mean that Sandra continues to consume mass cultural images, but she does so 
actively instead of passively. ${ }^{32}$ She always asks, it seems to me, "Who do they [the producers of mass culture] think they are?" To me, it is this capacity to consume brand names and simultaneously manage to reproduce them in quotation marks, that makes Sandra Bernhard "Sandra" and makes her a critical artist in our day. Not only does she "refuse to be the right sort of spectator" of mass culture, she disorients us enough so that we cannot swallow the food she gives us complacently. Finally, because of the way that Sandra reinterprets mass culture for us, we are forced to be the wrong sort of spectators of it as well.

\section{Notes}

I would like to thank Andrea Lawlor for her honest comments with regard to this essay, for her sycophancy, and for always being the right sort of wrong sort of spectator. Without her, I am nothing.

${ }^{1}$ Quoted in Daniel W. Conway and John E. Seery. The Politics of Irony: Essays in SelfBetrayal (New York: St. Martin's Press, 1991) 151. All subsequent references to this text will appear parenthetically in the text as Conway and Seery, followed by a page number.

${ }^{2}$ From Newsweek, quoted in Laurie Stone, "Nothing Ventured." Village Voice 12 April 1988: 95.

${ }^{3}$ Quoted in Lawrence Chua, "Guise and Dolls.” Village Voice 6 February 1990: 37.

${ }^{4}$ Bill Zehme, "Who's Afraid of Sandra Bernhard?" Rolling Stone 3 November 1988: 118.

${ }^{5}$ Lynn Hirschberg, “The Naked Sandra,"Vanity Fair August 1992: 141.

${ }^{6}$ Susan Sontag, "Notes on Camp," A Susan Sontag Reader (New York: Farrar, Straus \& Giroux, 1982) 109. Sontag capitalizes "Camp." The other writers do not. In this essay, the word will be capitalized only in direct quotes from Sontag.

${ }^{7}$ Her public persona in many of her interviews, for example, is as someone fierce, intimidating, ruthless, exacting, relentless. Most of her interviewers seem afraid of her. They are under her spell, as if they want to impress her, make her laugh, but their attempts at humor seem designed to feed Bernhard's hungry ego, metonymically represented by the mouth for which she is famous. Some of the titles of articles about her speak well to Bernhard's public image: "Sandra's Mouth," "Who's Afraid of Sandra Bernhard?," and "The Mouth that Roars," to name a few. Some of the best interviews, in fact, are those in which the interviewer seems to understand that she's only just "Sandra," "fierce" as she may be.

${ }^{8}$ Paul Taylor, "Sandra Bernhard," Interview March 1990: 141.

${ }^{9}$ All definitions of "sarcastic" and "ironic" are taken from The Second College Edition of the American Heritage Dictionary (Boston: Houghton Mifflin Company, 1985) 677, 1091. 
${ }^{10}$ Michael Musto, “Old Camp/New Camp," OUT April/May 1993: 34.

${ }^{11}$ Here I use the word queer to include more than just gay, lesbian, and bisexual identities. I mean to include, as Musto does, those performers amateur and professional who recognize their sexual identites as socially constructed in the post-structural sense of the word.

${ }^{12}$ Sontag does address camp as homosexual, but she does not extend this discussion to talk about drag, or any of its gender-bending practices.

${ }^{13}$ See, for instance, Joan Riviere's "Womanliness as Masquerade," and Judith Butler.

${ }^{14}$ Christopher Isherwood, from The World in the Evening London: Metheun, 1954. Quoted in Ross, 10.

${ }^{15}$ See Rhonda Lieberman's essay, “Glamorous Jewesses,” for an interesting discussion of Jewish divas, including Sandra Bernhard. Her discussion of the Jewish nose "puncturing the fantasy" of glamour and her assertion that Jewish women will "always [be] read as JAPS in Chanel" were influential in formulating my ideas about the connection between race and beauty.

16Jesse Green, “The Divine Sandra,” Mirabella August 1992: 39.

${ }^{17}$ In particular, see Mirabella, August 1992 for references to her "inflated" lips and “boxer's nose." In Rolling Stone, November 3, 1988, there is an interesting quote from her friend, "black comic" Paul Mooney, "She's thin, she's very aggressive, and she's got the big nigger lips. That's not what they [Hollywood] fall in love with. They were all threatened by her face, her sexuality" which I discuss later in the essay.

${ }^{18}$ Simone de Beauvoir, The Second Sex (New York: Bantam, 1952) 249.

${ }^{19}$ Gary Indiana, "Read My Lips (Without You I'm Nothing)," Village Voice 16 April 1989: 99.

${ }^{20}$ This scene seems to be in conversation with Madonna's movie Truth or Dare, released around the same time, which purports to display the "real, authentic" Madonna, behind the scenes of her tour. In her documentary, there are similar scenes in the dressing room, though Madonna's movie is not as overstated and for this reason appears less selfconsciously ironic. We might say that the film is campy, but it is naive camp, while Bernhard's is deliberate. Madonna, who tries to perform the authentic, appears inauthentic-humor is generated because we laugh at Madonna's naiveté. Bernhard's humor, which tries to be funny by performing the inauthentic and exposing it as such, ultimately relies on a common understanding of what is true or real or authentic. With Bernhard, it is less clear who the joke is on, us or her.

${ }^{21}$ The use of the phrase "smash-hit-one-woman-show" becomes the film's mantraa litany designed to invoke Sandra's mock egotism. Horn is shown with a pencil behind her ear, right of center, against a black screen. Although her responses to Sandra seem accurate, the off-center shot of Horn combined with her animated voice and gestures, make her testimony seem dubious - she makes the film a "mockumentary." 
${ }^{22}$ Horn's careful choice of the phrase, "to her roots," which deliberately evokes Alex Haley's epic novel, Roots, about the slavery of blacks in America, suggests that Sandra's "roots" are black. Again, we recognize that Sandra is inauthentic, as Horn falsely claims an artifical heritage or past for Sandra.

${ }^{23}$ Nina Simone and Stephen Cleary, I Put a Spell on You: The Autobiography of Nina Simone (New York: Pantheon, 1991) 117.

${ }^{24}$ Curiously and problematically, she skips the second verse which tells the story of "Safrona," with yellow skin, who tells the story of the rape of the black female slave and represents an example of someone who is often forced to "pass" in the real world, and not just on stage.

${ }^{25}$ Ryan Murphy, "Why Sandra Bernhard Is Not a Normal Girl," The Advocate 1 December 1991: 82.

${ }^{26}$ Can this might be read as an endorsement of the ways that our identities are always already mixed? Is Bernhard really saying that without each other we are nothing?

${ }^{27}$ This scene may speak to the heterosexualization of black women and the erasure of black lesbian and/or bisexual women, but is it an idictment of that process or reproduction of it? Does the film ultimately create a dichotomy between inauthentic, queer, hip white women and authentic, heterosexual, angry black women?

${ }^{28}$ The song is called "Straight Outta' Compton" and is about people who try to claim they're from Compton when they're not, or so I am told.

${ }^{29}$ This seems to echo the debate in feminism about deconstruction of the "subject" which feminists argue is problematic for the post-colonial subject in particular.

${ }^{30}$ Although I think that black women are "used" in this film in order to create comic juxtapositions rather than as "objects" of humor, or butts of the joke, Sandra Bernhard still colonizes their representation.

${ }^{31}$ I am grateful to Jane Desmond for pointing out the class conotations of this metaphor. It raises the question which haunts this essay: "Is Sandra Bernhard's humor intended for the racial and economic elite who eat themselves inadvertently, and think that they are eating a casserole of the Other or the common? Is the Other the spoonful of sugar that makes the medicine of the self go down? Is the 'Other' unable to consume itself? What is MTV if not a place which serves up the 'Other' for itself as well as for the elite?"

${ }^{32}$ C. Carr, “The Cave-Without You I'm Nothing,"Artforum 28 (1990): 23. 


\section{Works Cited}

Burana, Lily. "Sandra Bernhard: Acting Lesbian.” The Advocate 15 Dec. 1992: 66-73.

Carr, C. "The Cave_Without You I'm Nothing." Artforum 28 (1990): 22-23.

Chua, Lawrence. "Guise and Dolls.” Village Voice 6 Feb. 1990: 37-39.

Davy, Kate. "Fe/male Impersonation: The Discourse of Camp." Critical Theory and Performance. Ed. Janelle G. Reinelt and J.R. Roach. Ann Arbor: U of Michigan P, 1992. 231-47.

de Beauvoir, Simone. The Second Sex. New York: Bantam, 1952.

Green, Jesse. "The Divine Sandra." Mirabella Aug. 1992: 38-44.

Hirschberg, Lynn. “The Naked Sandra.” Vanity Fair Aug. 1992: 138-141.

hooks, bell. "Eating the Other." Black Looks Boston: South End, 1992. 21-39.

Hunt, Scott A.. "Sandra Bernhard: Outsider on the Inside track." Christopher Street 21 Dec. 1992: 15-18.

Indiana, Gary. "Read My Lips.” Village Voice 12 Apr. 1988: 99.

Lieberman, Rhonda. “Glamouress Jewesses.” Artforum 31 (1993): 5-6.

Murphy, Ryan. "Why Sandra Bernhard Is Not a Normal Girl." The Advocate 17 Dec. 1991: 82-83.

Musto, Michael. “Old Camp/New Camp.” OUT Apr./May 1993: 32-39.

Ross, Andrew. "Uses of Camp." The Yale Journal of Criticism 2 (1988): 1-24.

Simone, Nina, and Stephen Cleary. I Put a Spell On You: The Autobiography of Nina Simone. New York: Pantheon, 1991.

Sontag, Susan. "Notes on Camp." A Susan Sontag Reader New York: Farrar, Straus \& Giroux, 1982. 105-119.

Stillman, Deanne. "She Who Laughs Last.” Village Voice 12 Dec. 1989: 48.

Stone, Laurie. "Dark Victory." Village Voice 21 July 1992: 48-9.

Stone, Laurie. “Nothing Ventured.” Village Voice 12 Apr. 1988: 95.

Taylor, Paul. “Sandra Bernhard.” Interview 20 (1990): 136-141.

Young, Tracy. "Talking to...Sandra Bernhard.” Vogue Sept. 1988: 570.

Zehme, Bill. “Who's Afraid of Sandra Bernhard.” Rolling Stone 3 Nov. 1988: 76-80. 